Cervantes-Duarte, R., Prego, R., López-López, S., Aguirre-Bahena, F., and Ospina-Alvarez, N. (2013) Annual patterns of nutrients and chlorophyll in a subtropical coastal lagoon under the upwelling influence (SW of Baja-California Peninsula), Estuarine, Coastal and Shelf Science 120, 54-63.

\title{
ANNUAL PATTERNS OF NUTRIENTS AND CHLOROPHYLL IN A SUBTROPICAL COASTAL LAGOON UNDER THE UPWELLING INFLUENCE (SW OF BAJA-CALIFORNIA PENINSULA)
}

\author{
Rafael Cervantes-Duarte ${ }^{1,2}$, Ricardo Prego ${ }^{2}$, Silverio López-López ${ }^{1}$, Fernando Aguirre-Bahena ${ }^{1}$, \\ Natalia Ospina-Alvarez ${ }^{2}$ \\ ${ }^{1}$ Centro Interdisciplinario de Ciencias Marinas (CICIMAR). Av. Instituto Politécnico Nacional, s/n. 592 La Paz \\ BCS México. \\ ${ }^{2}$ Marine Research Institute (CSIC). Eduardo Cabello, 6. 36208 Vigo, Spain. \\ * corresponding author: prego@iim.csic.es
}

\begin{abstract}
The coastal lagoon of Bahía-Magdalena, located on the west coast of the Peninsula of Baja-California, is a subtropical ecosystem with an arid climate and very little freshwater input. During the 2005-2011 period the thermohaline properties varied between cold and warm halfyearly periods. They were influenced by the Transitional Water mass transported by the South California Current from February to July and by the Subtropical Surface Water from August to January. The nutrient concentrations increased (viz up to $16 \mu \mathrm{M}$ of nitrate) from March to June, when the upwelling index was the highest. Similarly, the inter-annual variation of chlorophyll- $a$ showed a six-monthly pattern with the highest average monthly concentrations being found in June ( $5 \mathrm{mg} \cdot \mathrm{m}^{-3}$ in situ or $8 \mathrm{mg} \cdot \mathrm{m}^{-3}$ based on satellite information) and the lowest in DecemberJanuary. A spatial zoning was also observed in the lagoon with a shallow inner zone that is warmer and richer in chlorophyll- $a$ than the deeper closed mouth area. In the Bahía-Magdalena lagoon a spatial-temporal division into two zones and two seasons was repeated year after year with only minor differences. During the first semester in the outer zone, years 2006 and 2007 were colder and nutrient rich while 2010 was warmer, according to the upwelling conditions in the Southern California Region. Hence, among the coastal lagoons that present a prevailing marine influence, the coastal system of Bahía-Magdalena corresponds to an unusual type of subtropical coastal lagoon where the nutrient input is mainly due to upwelling phenomena.
\end{abstract}

Keywords: inter-annual, intra-annual, biogeochemistry, California Current, chocked lagoon, BahíaMagdalena, Pacific coast, Mexico.

\section{1. - INTRODUCTION}

Continental shelf waters represent $8 \%$ of the Earth's oceanic surface but it is where nearly $25 \%$ of the primary sea production occurs (Walsh, 1989) and where a variety of types of coastal systems, which determine the exchange between land and sea, are found. In these systems, coastal lagoons, making up 13\% of the coastal areas worldwide, are predominant (Kjerve 1994). Coastal lagoons are inland water bodies, usually oriented parallel to the coast, separated from the sea by a barrier and connected to the ocean by one or more restricted inlets (Kjerfve and Magill 1989). In the subtropical climate region bordering, as delimited by Perillo et al. (1999), the Tropics of Cancer and Capricorn (23.5 latitude) and the temperate region ( $40^{\circ}$ latitude), coastal lagoons are subject to a wide climatic diversity ranging from monsoons to desert-like conditions. In all of these climate types the availability of nutrients restricts biological richness (Salomons et al., 2005). Despite this fact, subtropical coastal lagoons have not been studied extensively from a biogeochemical viewpoint, rather it is the ecological aspects that have undergone a more indepth examination (Kjerfve, 1994).

The wide variety of subtropical coastal lagoons have been classified according to the type of entrance channel into choked, restricted or leaky lagoons (Perillo et al., 1999), distinguished by the freshwater or marine prevailing influence (Abreu et al., 2010) or by the depth and substratum characteristics (Nichols and Boon, 1994). All the same, biological productivity in subtropical coastal lagoons is influenced by hydrodynamic processes such as water residence time (Badylak 
and Phlips 2004; Phlips et al., 2012), tidal mixing (Abreu et al., 2010) and water column turbidity (Caffrey et al., 2007). In addition to hydrographical factors, the type of littoral vegetation, i.e. salt marsh, mangle, seagrass and seaweed, is also relevant (Phlips et al., 2012; Badylak and Phlips 2004) as is the presence of populations of filtering macro-invertebrates, crustaceans and fishes, which may regulate phytoplankton dynamics (Badylak and Phlips 2004; Jiang et al., 2012).

A key factor in the primary production of subtropical coastal lagoons is nutrient input where the fluvial contributions may be essential (Coutinho and Mello 2011, Phlips et al., 2012). Upwelling events, rather than continental sources, are the main origin of nutrients transported to the photic layer (Hutchings et al., 1995). So, in the choked, restricted, and leaky lagoons of the arid regions found along the Pacific coast of Mexico (Gilmartin and Relevante, 1978) and southwestern Australia (Hodgkin and Lenanton, 1981), the new nutrients are principally supplied from the sea.

In Mexico there are 124 coastal lagoons (Lankford 1977) 60\% of which are situated in the subtropical region and $50 \%$ on the California Peninsula and its Gulf. The lagoons located on the western shore of Baja-California Peninsula $\left(32-23^{\circ} \mathrm{N}\right)$ from the San-Quintín lagoon $\left(40 \mathrm{~km}^{2}\right)$ to the north to the Bahía-Magdalena lagoon $\left(565 \mathrm{~km}^{2}\right)$ to the south are under the sea influence of the California Current. In this coastal zone the climate is dry and arid with northerly winds prevailing throughout the year. However, to the south of southern parallel $28^{\circ} \mathrm{N}$ south-westernly and westernly winds are common in summer and autumn (Zaitsev et al., 2010), which modifies the coastal hydrodynamic (Durazo et al., 2005; Durazo et al., 2011). The largest, deepest and southernmost lagoon of the Baja-California Peninsula, Bahia-Magdalena, is located in this area

Due to its wealth of marine resources, the ecological aspects of the aforementioned lagoon were studied extensively, as summarized in the review of Funes-Rodríguez et al. (2007). The nutrient cycle, however, received very little attention. Although the Bahía-Magdalena is the most well known system in the western Californian region, the inter- and intra-annual patterns of nutrient dynamics and, consequently chlorophyll- $a$ concentrations, still need to be examined in depth. The research carried out, as little as it is, points to the local importance of coastal upwelling (Álvarez-Borrego et al., 1975) and tidal currents (Acosta-Ruiz and Lara-Lara, 1978; Guerrero-Godínez et al., 1988) in the fertilization of the lagoon. On a large scale, the seasonally high biological production in the western lagoons of the Baja-California Peninsula might be connected with the conditions in the southern boundary of the California Current System (Durazo and Baumgartner, 2002; Durazo et al., 2005).

Therefore, in relation to nutrient input and phytoplankton activity (from chlorophyll levels), in the coastal lagoon of Bahía-Magdalena it is hypothesized that, as result of a prevailing marine influence, the fertilization process inside this lagoon is mainly due to coastal upwelling. In this way, the objectives are as follows: (i) to identify and characterize the main intra-annual periods highlighting the influence of the water masses that yearly are present in Bahia-Magdalena, in particular, Sub-Arctic Water, Equatorial Subsurface Water and the mixing of both of them, the Transitional Water; and (ii) to describe the inter-annual changes in the lagoon and to explore their relationship with the California Current System. These objectives are based on forty-three sampling cruises with a bimonthly frequency and 8-day composite satellite information for Surface Sea Temperature and chlorophyll- $a$. Data were used to analyze the seasonal and interannual variations for a period of seven years: from 2005 to 2011.

\section{2. - MATERIAL AND METHODS}

\section{1. - Study area}

The Bahía-Magdalena is a subtropical lagoon located on the southwestern coast of the peninsula of Baja-California (Figure 1). Following the classification system for Mexican lagoons (Lankford, 1977), Bahía-Magdalena has a tectonic structural origin and is a choked short inlet type of coastal lagoon (Perillo et al., 1999). The lagoon area covers $565 \mathrm{~km}^{2}$ with a total water volume (low-high tide) of 6.8-8.1 km (Sánchez-Montante et al., 2007). The lagoon is separated from the 
Pacific Ocean by Margarita and Magdalena islands and sand bars that are protected from ocean swells. The inner zone occupies half of the lagoon surface and is characterized by shallow channels $(<10 \mathrm{~m}$ in depth) surrounded by extensive mangrove areas. The deeper outer zone is connected to the ocean through a mouth $5.6 \mathrm{~km}$ wide and $38 \mathrm{~m}$ in depth. The sediment of the lagoon is relatively homogeneous with fine and very fine sands, except in the mangrove swamp area where sludge is abundant (Sanchez et al., 2010).

The offshore seawaters in Western Baja-California are under the influence of the southern boundary of the California Current; NW winds prevail during most of the year and frequent and intense upwelling events occur from April to June (Zaitsev et al., 2003; Cervantes-Duarte et al., 2010). In Bahía-Magdalena the weather is semi-arid. Air temperature ranges from $14^{\circ} \mathrm{C}$ in January to $32^{\circ} \mathrm{C}$ in August-September (Sánchez et al., 2010). The average annual precipitation varies between 48 and $153 \mathrm{~mm} \cdot \mathrm{yr}^{-1}$, collected mainly during summer (Sánchez et al., 2010). The lagoon does not receive river inputs and the continental freshwater sources are temporary streams. The tidal regime is semidiurnal and its range is microtidal: $0.4-2.3 \mathrm{~m}$ (Obeso-Nieblas et al., 1999). The phytoplankton consists mainly of diatoms and dinoflagellates (Garate-Lizarraga et al., 2007).

The population around the lagoon numbers approximately 10,000 inhabitants concentrated in the towns of Puerto-San-Carlos and Puerto-Adolfo-López-Mateos, whose main economic activity is artisanal fishery and the processing of tuna and sardine. The first of the two ports, Puerto-San-Carlos is also used to embark phosphorite, extracted from ores of neighboring inland areas.

\section{2. - Coastal cruises}

Forty-three one-day sampling cruises were carried out in the lagoon of Bahía-Magdalena during the period from 2005 to 2011 with a bimonthly frequency. The water column samples were taken aboard CICIMAR-XV and CICIMAR-XXX research boats, during ebb tide conditions, in fourteen stations in Bahía-Magdalena lagoon (Fig.1). Four of the stations were located in the outer or oceanic zone (St. A-D; >10 m depth) and the remaining ten are shallows ( $\leq 10 \mathrm{~m}$ depth) and correspond to the inner zone (St. 0-9) which is near to the littoral channels and mangroves where the freshwater inputs should occur. Vertical profiles of temperature and salinity were obtained at each station using a CTD Sea-Bird 19-Plus. Moreover, water samples from the surface and bottom were collected, but only surface samples were taken in the shallow stations (St.4-7), using 5-L General Oceanic Niskin bottles. Subsamples for the determination of nutrient salts and chlorophyll- $a$ were sampled from the bottles and refrigerated at $4^{\circ} \mathrm{C}$ to be processed in the port laboratory during the same day.

Air temperature in the lagoon was measured at the coastal meteorological station of SanCarlos (Fig.1). Data were provided by the Mexican "Comisión Nacional del Agua".

\section{3. - Sampling treatment and analyses}

Immediately after arrival at the port water samples were filtered using a Millipore system with fiberglass Whatman GFF filters of $25 \mathrm{~mm}$ in diameter. The content of the filter was used to extract the chlorophyll according to the procedure of Venrick and Hayward (1984) and next to quantify the chlorophyll concentration according to the Jeffrey and Humphrey (1975) method, using a Spectronic Genesys-2 spectrophotometer. One aliquot of the filtered water was used to determine the concentrations of ammonium, which were analyzed within 6 hours of collection. Another part was stored in a freezer at $-50^{\circ} \mathrm{C}$ for the subsequent analysis of nitrite, nitrate and phosphate. These nutrient salts were determined with the standard spectrophotometry method according to Strickland and Parsons (1972) using a Spectronic Genesys-2 device. The precision from ten replicate analyses was $\pm 0.1 \mathrm{mg} \cdot \mathrm{m}^{-3}$ for chlorophyll, $\pm 0.1 \mu \mathrm{M}$ for nitrate and ammonium, $\pm 0.01 \mu \mathrm{M}$ for nitrite and $\pm 0.03 \mu \mathrm{M}$ for phosphate.

The spatio-temporal division of lagoon in two zones and two seasons was tacked by water termohaline properties and biochemical characteristics one way ANOVA test analysis of principal components (PCA) applied to the seven years period. 


\section{4. - Satellite and upwelling index information}

Eight-day composite data for Sea Surface Temperature (SST) and chlorophyll a were used to analyze seasonal and inter-annual variation during the 2005-2011 period. Data were collected in the outer zone of the lagoon from the satellite MODIS-AQUA, Level-3 with $4 \times 4 \mathrm{~km}$ of spatial resolution available from ocean color home page: http:www.oceancolor.gsfc.nasa.gov/cgi/13. In situ data of SST and chlorophyll- $a$ from the deepest stations in the outer zone of the lagoon (St. AD) were averaged to be compared with the satellite data.

The periods of relaxation and intensification of the upwelling events were defined from the coastal upwelling index (UI) averaged every 8 days based on the data obtained daily from the

Fisheries Environmental Laboratory database (http://www.pfeg.noaa.gov/pfel/about_pfel.html).

The inter-annual variability of cold and warmer events was described on the basis of the Multivariate ENSO Index (MEI) and SST anomaly for the 2005 to 2011 period.

\section{3. - RESULTS}

\section{1. - Hydrographical conditions: thermohaline variables}

The sea surface temperature data in the Bahía-Magdalena lagoon come from in situ measurements (IST) recorded during sampling cruises and from satellite measured values (SST). The results are shown in Figure 2 where the IST averaged for the four stations of the outer lagoon zone is compared with the SST grid of this outer zone on the same day of the cruise. Temperature $\left({ }^{\circ} \mathrm{C}\right)$ from satellite and in situ are used both without distinction due to the correlation between their data was significant:

$$
\text { SST = 3.01+0.92.IST } \quad(r=0.94 ; n=43 ; p<0.05)
$$

The temperature range applied to this equation was $16-28^{\circ} \mathrm{C}$ and close to these limits. As observed in Fig.3, satellite estimations tend to be underestimated (overestimated) when the insitu temperature is low (high). Hence, during the period exhibiting the lowest annual temperature (winter-spring), the in-situ values are sometimes lower than the estimates recorded by satellite, while in the other period (summer-autumn) the opposite occurs (Figure 3).

Intra-annually the temperature in the lagoon of Bahia-Magdalena, according to both IST and SST, presented a markedly seasonal pattern with peaks from August to October and minima between March and May. There were no significant changes observed between surface and bottom temperatures $(p<0.05$; Table 1$)$ in the lagoon and in the water column, the stations nearest to the mouth were the coldest during the first half of year (Table 1). Of the two lagoon zones, the outer deeper oceanic zone had lower temperature readings throughout the year. than the inner zone, which is mainly littoral and shallow, This difference, however, was not significant during the second half of the year $(p<0.05$; Table 1$)$.

The water temperature in the upwelling areas is usually conditioned by the wind regime which moves the surface coastal waters seaward. This is quantified by the Upwelling Index (UI), which expresses the volume of water displaced by $\mathrm{km}$ of coastline during a given period of time. In the coastal area of the peninsula of Baja California adjacent to the lagoon of Bahía-Magdalena, the inter-annual variation of UI generally exhibits positive values (Fig.3), i.e. it is always favourable, to greater or lesser extent, to the upwelling year-round. Intra-annually upwelling conditions tend to present two peaks; one from March to May $\left(2000 \mathrm{~m}^{3} \cdot \mathrm{s}^{-1} \cdot \mathrm{km}^{-1}\right.$; Fig.2) and another from September to November $\left(1300 \mathrm{~m}^{3} \cdot \mathrm{s}^{-1} \cdot \mathrm{km}^{-1}\right.$; Fig.2). The maximum UI during the seven-year period covered was reached in March, April and May (particularly in the years 2006, 2010 and 2011), while some values of UI, averaged over eight-days, that were close to zero or negative, occurred in January-February and July-August.

Inter-annually, the temperature in the outer zone of the Bahía-Magdalena lagoon showed significant differences $(p<0.05)$ between the first and the second half of the year. In terms of extreme temperatures during the January-June interval of the 2005-2011 period, 2005 was the 
warmest year and 2008 the coldest, while during the July-December interval, the year 2008 was the warmest and 2010 the coldest (Fig.3). This annual pattern during the two seasons runs parallel to the oscillation of the air temperature (AT) in the littoral area of the lagoon (Fig.2). The monthly average maximum of AT was recorded in August $\left(34.3^{\circ} \mathrm{C}\right)$ and the minimum was found in January $\left(26.5^{\circ} \mathrm{C}\right)$ while the highest SST corresponded to the months of August-October (23.4$27.2^{\circ} \mathrm{C}$ ) and the lowest from March to May (16.8-20.4 ${ }^{\circ} \mathrm{C}$; Fig.2). If the inter-annual temperature fluctuations for the period 2005 to 2011 (Fig.3) are expressed as monthly SST anomalies, the alternation of warm and cold periods is emphasized. Hence, during the first half of 2005 the average anomalies were positive or warm $\left(+0.5^{\circ} \mathrm{C}\right)$ but during the second half of 2005 and the first half of 2006 , they were negative or cold $\left(-1.0^{\circ} \mathrm{C}\right)$. A similar warm-cold pattern was observed during the second half of 2006 and the first half of $2007\left(+1.5^{\circ} \mathrm{C}\right)$ and the second half of 2007 and the first half of $2008\left(-1.2^{\circ} \mathrm{C}\right)$. Later there were two extended periods of time; one was warm $\left(+1.5^{\circ} \mathrm{C}\right)$ from the second half of 2008 to the first half of 2010 and the other, cold $\left(-2.1^{\circ} \mathrm{C}\right)$ from the second half of 2010 to the first half of 2011.

While the temperature pattern is clear, salinity presented a complex temporal distribution with a mean value of $34.3 \pm 0.3$ (Fig.3). In temporal terms, the highest salinity was observed in the year 2011 and the lowest in 2005 (34.7 and 34.1, respectively; Fig.3). Spatially, the outer lagoon zone showed a less variable mean salinity $(34.2 \pm 0.2)$ in the first, rather than the second half of the year ( $34.4 \pm 0.4$; Table 1$)$. On the contrary, salinity variations in the inner zone were more obvious, reaching $35.0 \pm 0.7$ in the first half and $35.1 \pm 0.8$ in the second half of the year. In the water column of the lagoon, salinity did not exhibit any significant differences between the surface and the bottom $(p<0.05$; Table 1). However, salinities in the shallow inner area were significantly higher than in the mouth during both semesters ( $p<0.05$; Table 1 ).

Temperature and salinity values together make it possible to identify the water bodies that are present in the Bahia-Magdalena lagoon during the seven-year study period. The influence of upwelled seawater that reaches the lagoon must be higher near the bottom at the mouth. Thus the salinity and temperature data in the four stations of the outer lagoon zone are shown in a TS diagram (Figure 4). The data are clustered into three groups according to their own water mass characteristics: Sub-Arctic Water (SAW), Subropical Surface Water (StSW), Equatorial Subsurface Water (ESsW), and Transitional Water (TrW) from SAW and StSW mixing, following the water mass classification of Durazo and Baumgartner (2002) for the Pacific Oceanic Region of western Baja California.

During the first yearly period until June, T-S values are largely associated with TrW while in the second yearly period until December they belong to StSW in the inner and outer lagoon zones both (Fig.4). However, in the outer zone exceptions were observed for some months between the water masses associated with semi-annual seasons, mainly due to colder water conditions. During the first semester, in April 2006 and June 2006-07-08 the seawater values of temperature and salinity in the outer lagoon zone corresponded to ESsW instead of TrW. Similarly, during the second semester the seawater in August 2007 and December 2007 and 2010 shifted from StSW to TrW. In the inner zone of lagoon the salinity increases up to 38 , mainly during summer.

\section{2. - Biogeochemical conditions: nutrients and chlorophyll-a distribution}

Concentrations of nutrient salts in Bahia-Magdalena waters did not exceed values of 16,1 , 19 and $3 \mu \mathrm{M}$ for nitrate, nitrite, ammonium and phosphate, respectively. Although silicate cannot be determined in the 2005-2011 period corresponding to the present study, a previous analysis (2001-03; Cervantes-Duarte, pers. comm.) indicated that its concentration did not exceed $18 \mu \mathrm{M}$.

Intra-annually, the mean concentrations of nitrate and phosphate in the water lagoon were higher during the first half of the year (Table 1). There is a significant seasonal (i.e. six-monthly) difference (Table 1) for the two nutrients between the inner and outer zones of lagoon. Figure 5 shows a good seasonal correlation for each semester of the seven aforementioned years between both nutrients $(\mu \mathrm{M})$ in the outer lagoon zone:

$$
\text { First semester: } \quad \text { [nitrate] }=8.44 \text { [phosphate] }-3.0 \quad(r=0.95 ; n=7)
$$


Second semester: [nitrate] $=1.82$ [phosphate] $-0.2 \quad(r=0.84 ; n=7)$

During the first half-yearly season, the availability of nitrate and phosphate is higher than in the second season. Intra-annually, the higher influence of upwelling during the first semester was in parallel to nutrient increase (Fig.3). Moreover, there was also observed inter-annually variations of nutrients (Fig.3), i.e. in 2006 (5.8 and $1.0 \mu \mathrm{M}$ of nitrate and phosphate, respectively), $2007(3.9$ and $0.85 \mu \mathrm{M}), 2010(2.7$ and $0.64 \mu \mathrm{M})$ and $2011(2.5$ and $0.68 \mu \mathrm{M})$.

The mean concentration of ammonium was higher during the first half of the year, but, unlike nitrate and phosphate, ammonium does not exhibit any significant differences between the external and internal areas of the lagoon or between the surface and bottom (Table 1) during this season. This spatial homogeneity does not continue on a temporal basis since there are statistically significant differences between the first and second half of the year (Table 1), associated with a greater concentration of ammonium near the littoral zone during the second season.

In the Bahia-Magdalena lagoon chlorophyll concentrations reached $17 \mathrm{mg} \cdot \mathrm{m}^{-3}$ and the dissolved oxygen saturation percentage varied between $70-130 \%$, which indicates a high biological activity associated with the availability of nutrient salts reported earlier. The mean concentrations of chlorophyll- $a$ in the stations close to the mouth of the lagoon, i.e. its outer zone, were comparatively higher during the first versus the second half of the year ( 2.8 and 1.7 $\mathrm{mg} \cdot \mathrm{m}^{-3}$, respectively; Table 1 ). Chlorophyll- $a$ ranges did not show any significant differences $(p<0.05)$ between the surface and bottom areas of the whole lagoon, but in both semesters, the concentration of Chlorophyll- $a$ increased in the inner zone close to the shallow littoral zone, (2.2$3.5 \mathrm{mg} \cdot \mathrm{m}^{-3}$; Table 1). The annual variation in chlorophyll showed a six-monthly pattern with its highest concentrations found at the end of the first season and the lowest at the end of the second season (Fig.2).

The chlorophyll- $a$ analysis from in situ and satellite values, was significant. However, the values estimated from satellite measurements had a greater dynamic range with respect to the measurement in situ (Fig.2). The correlation between both estimates was:

Chlorophyll-a $\left(\mathrm{mg} \cdot \mathrm{m}^{-3}\right): \quad$ [satellite] $=1.76$ [in situ $]-0.20 \quad(\mathrm{r}=0.74 ; \mathrm{n}=42 ; \mathrm{p}<0.05)$

The overestimation of chlorophyll- $a$ concentrations from satellite measurements was already pointed out in the region of California Current by Kahru and Mitchell (2001). These authors indicated that the chlorophyll- $a$ correlation between satellite and in situ data is higher offshore than near the coast. It may be associated with the inshore increase of colouring dissolved organic matter from sources different to phytoplankton.

Inter-annually, both satellite and in situ trends were similar in the lagoon. The period from 2005 to 2011 showed increases in the average concentrations of chlorophyll in $2008\left(3.0 \mathrm{mg} \cdot \mathrm{m}^{-3}\right.$; Fig.3) and $2010\left(2.7 \mathrm{mg} \cdot \mathrm{m}^{-3}\right)$, while $2009\left(1.8 \mathrm{mg} \cdot \mathrm{m}^{-3}\right), 2006$ and $2011\left(2.0 \mathrm{mg} \cdot \mathrm{m}^{-3}\right)$ were less productive years. This inter-annual chlorophyll- $a$ pattern correlates with the temperature (Fig.5) of the outer lagoon zone. There, the chlorophyll- $a$ concentration increases when the water temperature decreases. This occurs during the two seasons of the year in the lagoon, although during the second season, the temperature was higher and the levels of chlorophyll-a lower. In both cases there was a good correlation between chlorophyll-a concentration ( $\mathrm{Chl}-a$ in $\mathrm{mg} \cdot \mathrm{m}^{-3}$ ) and temperature $\left({ }^{\circ} \mathrm{C}\right)$ in the outer lagoon zone:

$$
\begin{array}{lll}
\text { First semester: } \quad[\mathrm{Chl}-a]=13.4-0.62 \cdot \mathrm{T} & (\mathrm{r}=0.93 ; \mathrm{n}=6) \\
\text { Second semester: }[\mathrm{Chl}-a]=9.2-0.32 \cdot \mathrm{T} & (\mathrm{r}=0.83 ; \mathrm{n}=6)
\end{array}
$$

\section{3. - Spatio-temporal zoning}

The main oceanographic patterns in the subtropical lagoon of Bahía-Magdalena during the 2005-2011 period can be studied on the basis of the variables measured seasonally and averaged every year, i.e. the first (February-July) and second (August-January) semester, in each lagoon zone, i.e. inner and outer areas. Therefore, a factorial analysis may explain the response variables during those seven years, as a function of explanatory thermohaline and biogeochemical variables. This resulted in the extraction of two factors that explain $64 \%$ of the variance in the PCA 
of Figure 6 . Factor 1 (37\% of the contribution to the total variance) displayed high positive scores for nutrient salts (nitrate, ammonium and phosphate), and negative scores for temperature and oxygen saturation. Factor 2 (27\% of the contribution to the total variance) loaded positively in salinity and chlorophyll- $a$, and negatively in the depth of the Secchi disk. It provided an annual season-zone division to the lagoon following the four quadrants of PCA regardless of the year. The fist quadrant comprises the inner zone and the first season; the second, the outer zone and first season; the third, the outer zone and second season; and the fourth, the inner zone and second season (Fig.6).

\section{4. - DISCUSSION}

Thermohaline and biogeochemical variables were able to identify an inner zone that is associated with depths lower than $20 \mathrm{~m}$ in the subtropical lagoon of Bahía-Magdalena. This shallow zone occupies approximately $80 \%$ of the lagoon area and it is characterized by a homogeneous vertical distribution of salinity and temperature. Salinity increased near the littoral, where there are intertidal channels, and during summer. According to the explanation given by Zaitsev et al. (2010) it has to do with the main physical processes affecting the thermohaline structure, such as tidal transport and surface heat in Bahia-Magdalena. Moreover, this vertical homogeneity may be extended to the nutrients and chlorophyll in the water column of the shallow lagoon zone. This inner pattern is due to the absence of freshwater contributions towards the lagoon, which is located in a semi-arid climate region. This fact makes a key difference between Bahia-Magdalena and other subtropical lagoons where the fluvial contributions fertilize the inner areas and give rise to a vertical stratification in salinity and nutrients (Caffrey et al., 2007; Murrell et al., 2007; Phlips et al., 2012). So, in the subtropical lagoons with estuarine zones the nutrient inputs are mainly connected with the rainfall season (Eyre 2000; Lehrter 2008; Abreu et al., 2010) and chlorophyll concentration increased up to four times the observed during the dry season (Phlips et al., 2012). On a local level in Bahia-Magdalena, the presence of a mangle forest in the littoral zone (Acosta Velázquez and Ruiz-Luna, 2007) and the phosphorite ores from neighboring areas that are loaded at San-Carlos port increased the ammonium and phosphate concentrations in the shore waters.

Consequently, in keeping with the typology of Abreu et al. (2010), Bahia-Magdalena can be classified among the coastal lagoons which have a prevailing marine influence, such as was emphasized by the salinities higher than 35 in the inner lagoon zone, showing the very scarce continental freshwater inputs during all the year (Fig.4). It is in the outer zone of the lagoon where the influence of the sea can be clearly identified. This outer zone is characterized by its situation close to the sea-mouth of the lagoon and depths greater than $20 \mathrm{~m}$. Temperaturesalinity diagrams show the influence of upwelling events within the lagoon (Fig.4). The incoming seawater corresponds to the typical water mass classification off the western coast of Baja California (Durazo and Baumgartner 2002). Therefore, the three main groups of the Pacific Oceanic Region of western Baja California (Durazo and Baumgartner, 2002) have been observed in the lagoon: TrW in the California Current (CCW), and to a lesser extent ESsW, prevailing during the February-July season, while StSW was mainly associated with the August-January season (Fig.4). The boundary between the seawater transported by CCW, i.e. TrW and SAW, and the saltier and warmer StSW, i.e. the temperate-tropical transition (Lluch-Belda et al., 2003), moves northward during late summer and fall. Then, tropical and subtropical waters are observed farther to the north (Durazo, 2009). In this annual period, the coastal lagoon of Bahía-Magdalena was under the domain of StSW while the influence of the CCW coincided in time with the intensification of the California Current (Schwartzlose and Reid 1972), associated with the coastal upwelling induced by the prevailing north-westerly wind in the period from March to June.

Bahía-Magdalena belongs to the type of marine-domain coastal lagoon, but unlike the most of these subtropical types, Bahia-Magdalena is different because it is situated in a perennial upwelling region. However, upwelling is not a temporally continuous or spatially uniform process; 
rather it displays periods of more favourable conditions. Along the entire coast of the peninsula of California, the upwelling intensity changes in accordance with local wind conditions and bottom topography (Zaitsev et al., 2003). There is an intensification of the spring upwelling activity towards the middle latitudes. Average UI magnitudes for the Magdalena Bay latitude $\left(24^{\circ} \mathrm{N}\right)$ were three times lower than for the Ensenada location $\left(31^{\circ} \mathrm{N}\right)$ for the period from April through June. Moreover, the duration of upwelling events is also shorter in Bahía-Magdalena, 4-5 days (Zaitsev et al., 2003; Durazo et al., 2010) than in the north-eastern zone, i.e. two weeks at Point Conception $\left(34.5^{\circ} \mathrm{N}\right.$; Wilkerson et al., 2006). There is a very little scientific knowledge on subtropical coastal-upwelling lagoons although at $30^{\circ} \mathrm{N}$ on the Californian Peninsula there is another similar coastal system, the Bahía-de-San-Quintín (42 km $\mathrm{km}^{2}$ and $20 \mathrm{~m}$ in depth at its mouth). In this subtropical lagoon influenced by the California Current System, upwelling events and tides are the main causes of variability in the lagoon's hydrographical properties (Millan-Nuñez et al., 1982; Alvarez-Borrego, 2004).

The temporal pattern in the Bahia-Magdalena lagoon shows the nutrient dependence of upwelling events (Fig.3). So, among the coastal lagoons presenting a prevailing maritime influence (Abreu et al., 2010), this coastal system corresponds to an unusual type of subtropical coastal lagoon where its water is under fertilization by upwelling phenomena. This Bahia-Magdalena pattern was also observed in temperate ria systems (Evans and Prego, 2003) with seasonal upwelling (Fraga, 1981; Prego and Bao, 1997). During spring-summer in the Western and Middle Galician Rias of the Iberian Peninsula the fluvial contributions are very low; hence nutrient input as result of upwelling events is the main reason for the fertilization of the ria (Prego, 2002; Varela et al., 2008). In both systems, the subsurface nutrient-rich water upwells: The Eastern North Atlantic Central water mass in the case of the rias (up to $12 \mu \mathrm{M}$ of nitrate; Prego et al., 1999) and the Sub-Arctic water mass in the California Current in the case of Bahia-Magdalena, which is below $100 \mathrm{~m}$ depth and upwells to the surface (Zaitsev et al., 2003; Durazo 2009; Durazo et al., 2010). Under upwelling conditions in the western shelf of the Baja-California region, Pennington and Chávez (2000) indicated nitrate concentrations of 7-20 $\mu \mathrm{M}$ in the Bay of Monterey, from May to June and Ribas-Ribas et al. (2011) measured up to $12 \mu \mathrm{M}$ of nitrate in the Bay of San-Quintín. Moreover, during the period of high upwelling intensity (March-June) nitrate concentrations increased up to $15 \mu \mathrm{M}$ in the Bahía-Magdalena lagoon. The phytoplankton pattern in this lagoon (Gárate-Lizarraga et al., 2007) and the chlorophyll-a concentrations (Fig.2), both of which increased to reach maximum values in June, allow for a high exploitation of marine resources (fishes, mollusks and crustaceans; Funes-Rodríguez et al., 2007) in the Bahía-Magdalena lagoon. It is mainly supported by nutrient inputs from upwelling in the February-July period.

The spatial (inner and outer areas) and temporal (February-July and August-January semesters) duality of the subtropical lagoon of Bahía-Magdalena during the 2005-2011 period is repeated year to year. The PCA grouping (Fig.6) shows how the intra-annual pattern is recurrent according to the pattern described in the previous section. The oceanographic parameters in the outer lagoon zone during the 2005-2011 period ( $\mathrm{M}$ points in the Fig.6) varied between cold and warm half-yearly periods in association with the California Current water and Subtropical Surface Water alternation off the Baja-California region (Goericke et al., 2007; Bjorkstedt et al., 2010).

In this trend some minor differences can be noticed. During the first semester in the outer lagoon zone, 2006 and 2007 are the furthest on the X-axis of Fig.6, which implies that they are the coldest $\left(17.2\right.$, and $17.9^{\circ} \mathrm{C}$, respectively) and most nutrient abundant years (9.8 and $6.1 \mu \mathrm{M}-\mathrm{NO}_{3}$, respectively) of the seven years period. The meteorological conditions of these two years presented an increase in the upwelling tailwinds of the southern California Current region (Peterson et al., 2006; Goericke et al., 2007). On the contrary, upwelling intensities were low the years 2010 and 2011 and there were low differences between chlorophyll-a concentrations between their first and second semester seasons (Fig. 3 and equations 5 and 6). Both semesters were close together in the inner lagoon zone (Fig.6), which indicates that no significant 
differences occurred throughout these years. Moreover, in 2010-11 the points corresponding to the outer zone and the first semester were closest to the X-origin (Fig.6), i.e. a year with low upwelling intensities. During 2005 and 2010 unusually cold waters were recorded in the south California region, resulting from intense upwelling (Peterson et al., 2006), but there was no information on the Bahía-Magdalena coast. However, in spring 2010, warm conditions were observed together with an increase in gelatinous zooplankton (Bjorkstedt et al., 2010). Lastly, 2009 was an unusual year with regard to the position of the outer points close to the end of the negative ordinate axis (Fig.6); 2009 was an atypical year. During 2009, the negative Pacific Decadal Oscillation index of 2007-08 returned to normal (McClatchie et al., 2009).

In the world, different temporal trends were observed as result of the climate forcing on the upwelling variability. So, in the California Current region $\left(32-40^{\circ} \mathrm{N}\right)$ an increase in the seasonal upwelling was pointed out by Schwing and Mendelssohn (1998), similarly to those reported for the coastal upwelling areas off North-West Africa and Peru (Bakun 2001; Narayan et al. 2010). The time series of seven years (2005-2011) obtained in the Bahía-Magdalena lagoon show an ambiguous trend, in accordance with the $24-27^{\circ} \mathrm{N}$ result from the latitudinal model developed by Bakun (1990). However, Kahru et al. (2012) detected a decrease in the chlorophyll concentration in the Southern Baja-California zone; they attributed it to a reduction in the upwelling intensity. It can be speculate that the upwelling decrease in the Bahía-Magdalena lagoon should modify the chlorophyll levels during the boundary months between the two seasons; so, the warm pattern will prevail over the cold and the lagoon could become biologically less productive. Longer time series in Bahía-Magdalena lagoon are necessaries for researching the impact of climate on oceanographic changes.

Acknowledgements. The authors would like to thank Sonia Futema Jiménez and Francisco Barrera González for their technical assistance in sampling, analysis and data processing; to two anonymous referees for their detailed and valuable comments; and to Ms. Claire P. Teed for her review of the English language. This article was supported by the SIP Mexican projects of the Instituto Politécnico Nacional from 2005 to 2011 in cooperation with the Spanish project CTM2011-28792-C02 financed by the 'Ministerio de Economía y Competitividad'. We are very grateful to the Mexican COFAA (IPN) organism and EDI program for their grants and to the Mexican governmental agency CONACYT for financing the sabbatical (ref. 169030) of Dr. Rafael Cervantes-Duarte at the IIM (CSIC) of Spain during 2012.

\section{REFERENCES}

Abreu, P.C., Bergesch, M., Proença, L.A., Garcia, C.A.E. and Odebrecht, C., 2010. Short- and LongTerm Chlorophyll a Variability in the Shallow Microtidal Patos Lagoon Estuary, Southern Brazil. Estuaries and Coasts 33, 554-569.

Acosta-Velázquez, J, and Ruiz-Luna, A., 2007. Variación en la cobertura, distribución y estructura de los manglares del complejo lagunar Bahía Magdalena-Bahía Almejas (1990-2005). In: Funes-Rodríguez, R., Gómez-Gutiérrez J. and Palomares-García R. (Eds.). Estudios ecológicos en Bahía Magdalena. Ed. CICIMAR, IPN, La Paz, Baja California Sur, México, pp. 127-141.

Acosta-Ruíz, M. and Lara-Lara J., 1978. Resultados físico-químicos de un estudio de variación diurna en el área central de Bahía Magdalena, BCS. Ciencias Marinas 5, 37-46.

Álvarez-Borrego, S., 2004. Nutrient and phytoplankton dynamics in a coastal lagoon strongly affected by coastal upwelling. Ciencias Marinas 30, 1-19.

Álvarez-Borrego, S., Galindo-Bect, L.A., Chee-Barragán, A., 1975. Características hidroquímicas de Bahía Magdalena, BCS. Ciencias Marinas 2, 94-110. 
Badylak, S. and Phlips, J., 2004. Spatial and temporal patterns of phytoplankton composition in a subtropical coastal lagoon, the Indian River Lagoon, Florida, USA. Journal of Plankton Research 26, 1229-1247.

Bakun, A., 1990. Global climate change and intesification of coastal ocean upwelling. Science 247, 198-201.

Bakun, A. \& V. N. Agostini, 2001. Seasonal patterns of wind-induced upwelling/downwelling in the Mediterranean Sea. Scientia Marina 65, 243-257.

Bjorkstedt, E.P., Goericke, R., McClatchie, S., Weber, E., Watson, W., Lo, N., Peterson, B., Emmett, B., Peterson, J., Durazo, R., Gaxiola-Castro, G., Chavez, F., Pennington, J.T., Collins, C.A., Field, J., Ralston, S., Sakuma, K., Bograd, S.J., Schwing, F.B., Xue, Y., Sydeman, W.J., Thompson, S.A., Santora, J.A., Largier, J., Halle, C., Morgan, S., Kim, S.Y., Merkens, K.P.B., Hildebrand, J.A. and Munger, L.M., 2010. State of the California current 2009-2010: Regional variation persists through transition from la Niña to el Niño (and back?). California Cooperative Oceanic Fisheries Investigations Reports 51, 39-69.

Caffrey, J.M., Chapin, T.P., Jannasch, H.W. and Haskins, J.C., 2007. High nutrient pulses, tidal mixing and biological response in a small California estuary: Variability in nutrient concentrations from decadal to hourly time scales. Estuarine, Coastal and Shelf Science 71, 368-380.

Cervantes-Duarte, R., López-López, S., González-Rodríguez, E. and Futema-Jiménez, S., 2010. Ciclo estacional de nutrientes, temperatura, salinidad y clorofila a en Bahía Magdalena, BCS, México (2006-2007). CICIMAR Oceánides 25, 111-120.

Coutinho, H.M. and Mello, P.M., 2011. Spatial and temporal dynamic of trophic relevant parameters in a subtropical coastal lagoon in Brazil. Environmental Monitoring and Assessment 181, 347-361.

Durazo, R, 2009. Climate and upper ocean variability off Baja California, Mexico: 1997-2008, Progress in Oceanography 83, 361-368.

Durazo, R., Baumgartner, T.R., 2002. Evolution of oceanographic conditions off Baja California: 1997-1999. Progress in Oceanography 54, 7-31.

Durazo, R., Gaxiola-Castro, G., Lavaniegos, B., Castro-Valdez, R., Gómez-Valdés, J. and Mascarenhas Jr., A.D.S., 2005. Oceanographic conditions west of the Baja California coast, 2002-2003: A weak El Niño and subarctic water enhancement. Ciencias Marinas 31, 537552.

Durazo, R., Ramírez-Manguilar, A.M., Miranda, L.E., Soto-Mardones, L.A., 2010. Climatología de variables hidrográficas. In: Gaxiola-Castro, G., Durazo, R. (Eds.), Dinámica del Ecosistema Pelágico frente a Baja California, 1977-2007: Diez años de Investigaciones Mexicanas de la Corriente de California, Secretaría de Medio Ambiente y Recursos Naturales, México D.F., pp. 25-57.

Evans, G., Prego, R., 2003. Rias, estuaries and incised valleys: is a ria an estuary? Marine Geology $196,171-175$.

Eyre, B.D., 2000. Regional evaluation of nutrient transformation and phytoplankton growth in nine river-dominated subtropical east Australian estuaries. Marine Ecology Progress Series 205, 61-83.

Fraga, F., 1981. Upwelling off the Galician coast, northwest Spain. In: Richards, F.A. (Ed.), Coastal Upwelling. AGU, Washington, pp. 176-182.

Funes-Rodríguez, R., Gómez-Gutierrez, J. and Palomares-García, R., 2007. Estudios Ecológicos en Bahía Magdalena, Ed. CICIMAR, IPN, La Paz, Baja California Sur, México, 311 pp.

Gárate-Lizárraga, I., Band-Schmidt, C.J., Verdugo-Díaz, G., Muñetón-Gómez, M.S. and Félix-Pico, E.F., 2007. Dinoflagelados (Dinophyceae) del sistema lagunar Magdalena-Almejas. In: FunesRodríguez, R., Gómez-Gutiérrez J. and Palomares-García R. (Eds.). Estudios ecológicos en Bahía Magdalena. Ed. CICIMAR, IPN, La Paz, Baja California Sur, México, pp. 145-174

Gilmartin, M. and Revelante, N., 1978. The Phytoplankton Characteristics of the Barrier Island Lagoons of the Gulf of California. Estuarine and Coastal Marine Science 7, 29-47. 
Goericke, R., Venrick, E., Koslow, T., Sydeman, W.J., Schwing, F.B., Bograd, S.J., Emmett, R., Peterson, W.T., Rubén Lara Lara, J., Castro, G.G., José, G.V., Hyrenbach, K.D., Bradley, R.W., Weise, M.J., Harvey, J.T., Collins, C. and Lo, N.C.H., 2007. The state of the California current, 2006-2007: Regional and local processes dominate. California Cooperative Oceanic Fisheries Investigations Reports 48, 33-66.

Guerrero-Godinez, R., Cervantes-Duarte, R. and Jiménez-Illescas, A.R., 1988. Nutrient variations during a tidal cycle at the mouth of a coastal lagoon in the northwest of México. Indian Journal of Marine Sciences 17, 235-237.

Hutchings, L., Pitcher, G.C., Probyn, T.A. and Bailey, G.W., 1995. The chemical and biological consequences of coastal upwelling. In: Summerhayes, C.P., Emeis, K.C., Angel, M.V., Smith, R.L. and Zeitzschel, B. (Eds.). Wiley, Chichester, pp. 65-82.

Hodgkin, E.P. and Lenanton, R.C., 1981. Estuaries and coastal lagoons of southwestern Australia. In Estuaries and Nutrients (Nielsen, B.J. and Cronic, I.E., eds.). Harman Press, New Jersey, pp. 307-321.

Jiang, Z.-., Chen, Q.-., Zeng, J.-., Liao, Y.-., Shou, L. and Liu, J., 2012. Phytoplankton community distribution in relation to environmental parameters in three aquaculture systems in a Chinese subtropical eutrophic bay. Marine Ecology Progress Series 446, 73-89.

Kahru, M. and Mitchell, B.G., 2001. Seasonal and nonseasonal variability of satellite-derived chlorophyll and colored dissolved organic matter concentration in the California Current. Journal of Geophysical Research 106 C2, 2517-2529.

Kahru, M., Kudela, R.M., Manzano-Sarabia, M. and Mitchell, B.G., 2012. Trends in the surface chlorophyll of the California Current: Merging data from multiple ocean color satellites. Deep-Sea Research II 77-80, 89-98.

Kjerfve, B.J. 1994. Coastal Lagoons. In: Kjerfve, B.J. (Ed.), Coastal Lagoon Processes. Elsevier Science Publishers B.V. Elsevier Oceanographic Series, 60. Elsevier, New York, pp. 1-8.

Kjerfve, B.J. and Magill, K.E., 1989. Geographic and hydrodinamic characteristics of shallow coastal lagoons. Marine Geology 88, 187-199.

Lankford, R.R., 1977. Coastal Lagoons of Mexico. Their origin and classification. In: Wiley, M.L., (Ed.), Estuarine Processes 2, Academic Press, New York, pp. 182-216.

Lehrter, J.C., 2008. Regulation of eutrophication susceptibility in oligohaline regions of a northern Gulf of Mexico estuary, Mobile Bay, Alabama. Marine Pollution Bulletin 56, 1446-1460.

Lluch-Belda, D., Lluch-Cota, D.B. and Lluch-Cota, S.E., 2003. Baja California's biological transition zones: refuges for the California sardine, Journal of Oceanography 59, 503-513.

McClatchie, S., Goericke, R., Schwing, F.B., Bograd, S.J., Peterson, W.T., Emmett, R., Charter, R., Watson, W., Lo, N., Hill, K., Collins, C., Kahru, M., Mitchell, B.G., Koslow, J.A., Gomez-Valdes, J., Lavaniegos, B.E., Gaxiola-Castro, G., Gottschalck, J., L'Heureux, M., Xue, Y., ManzanoSarabia, M., Bjorkstedt, E., Ralston, S., Field, J., Rogers-Bennet, L., Munger, L., Campbell, G., Merkens, K., Camacho, D., Havron, A., Douglas, A. and Hildebrand, J., 2009. The state of the California Current, spring 2008-2009: Cold conditions drive regional differences in coastal production. California Cooperative Oceanic Fisheries Investigations Reports 50, 43-68.

Millan-Nuñez, R., Alvarez-Borrego, S. and Nelson, D.M., 1982. Effects of physical phenomena on the distribution of nutrients and phytoplankton productivity in a coastal lagoon. Estuarine, Coastal and Shelf Science 15, 317-335.

Murrell, M.C., Hagy III, J.D., Lores, E.M. and Greene, R.M., 2007. Phytoplankton Production and Nutrient Distributions in a Subtropical Estuary: Importance of Freshwater Flow. Estuaries and coasts 30, 390-402.

Narayan, N., Paul, A., Mulitza, S. and Schulz, M., 2010. Trends in coastal upwelling intensity during the late 20th Century. Ocean Science Discussion 7, 335-360.

Nichols, M.M. and Boon, J.D., 1994. Sediment Transport Processes in Coastal Lagoons. In: Kjerfve, B.J. (Ed.), Coastal lagoon processes. Elsevier Oceanographic Series, 60. Elsevier, New York, pp. 157-219. 
Obeso-Nieblas, M., Gaviño-Rodríguez, J.H. and Jiménez-Illescas, A.R., 1999. Modelación de la marea en el sistema lagunar Bahía Magdalena-Almejas, B.C.S., México. Oceánides 14, 79-88.

Pennington, J.T. and Chávez, F.P., 2000. Seasonal fluctuations of temperature, salinity, nitrate, chlorophyll and primary production at station H3/M1 over 1989-1996 in Monterey Bay, California. Deep-Sea Research 47, 947-973.

Perillo, M.E.G., Piccolo, C.M. and Pino-Quivira, M. 1999. What do we know about the Geomorphology and Physical Oceanography of South American Estuaries?. In: Perillo, M.E.G., Piccolo, M.C. and Pino-Quivira, M. (Eds.), Estuaries of South America. Their Geomorphology and Dynamics. Springer-Verlag Berlin Heidelberg, pp. 1-14.

Phlips, E.J., Badylak, S., Hart, J., Haunert, D., Lockwood, J., O'Donnell, K., Sun, D., Viveros, P. and Yilmaz, M., 2012. Climatic Influences on Autochthonous and Allochthonous Phytoplankton Blooms in a Subtropical Estuary, St. Lucie Estuary, Florida, USA. Estuaries and Coasts 35, 335-352.

Peterson, B., Emmett, R., Ralston, S., Forney, K.A., Chavez, F., Benson, S., Goericke, R., Venrick, E., Mantyla, A., Hewitt, R., Lo, N., Watson, W., Barlow, J., Lowry, M., Sydeman, W.J., Hyrenbach, D., Bradley, R.W., Warzybok, P., Weise, M., Bograd, S.J., Schwing, F.B., Lavaniegos, B.E., Hunter, K. and Harvey, J., 2006. The state of the california current, 20052006: Warm in the north, cool in the south. California Cooperative Oceanic Fisheries Investigations Reports 47, 30-74.

Prego, R., 2002. Nitrogen Fluxes and Budget Seasonality in the Ria Vigo (NW Iberian Peninsula). Hydrobiologia 475/476, 161-171

Prego, R., Bao, R., 1997. Upwelling influence on the Galician coast: silicate in shelf water and underlying surface sediments. Continental Shelf Research 17, 307-318.

Prego, R., Barciela, C., Varela, M., 1999. Nutrient dynamics in the Galician coastal area (Northwestern Iberian Peninsula): Do the Rias Bajas receive more nutrient salts than the Rias Altas? Continental Shelf Research 19, 317-334.

Ribas-Ribas, M., Hernández-Ayón, J.M., Camacho-Ibar, V.F., Cabello-Pasini, A., Mejia-Trejo, A., Durazo, R., Galindo-Bect, S., Souza, A.J., Forja, J.M. and Siqueiros-Valencia, A., 2011. Effects of upwelling, tides and biological processes on the inorganic carbon system of a coastal lagoon in Baja California. Estuarine, Coastal and Shelf Science 95, 367-376.

Sánchez, A., Choumiline, E., López-Ortiz, B.E., Aguíñiga, S., Sánchez-Vargas, L., RomeroGuadarrama, A. and Rodríguez-Meza, D., 2010. Patrón de transporte de sedimento en Bahía Magdalena, Baja California Sur México, inferido del análisis de tendencias granulométricas. Latin American Journal of Aquatic Research 38, 167-177.

Sánchez-Montante, O., Zaitsev, O. and Saldivar-Reyes, M., 2007. Condiciones hidrofisicas en el sistema lagunar Bahía Magdalena-Almejas. In: Funes-Rodríguez, R., Gómez-Gutiérrez, J. and Palomares-García R. (Eds.), Estudios Ecológicos en Bahía Magdalena. Ed. CICIMAR, IPN, La Paz, Baja California Sur, México, pp. 1-28.

Salomons, W., Hartwig, H., Kremer, H. and Turner, K., 2005. The catchment to coast continuum. In: Crossland C.J, Kremer H.H, Lindeboom H.J, Marshall-Crossland J.I, Le Tissier M.D.A (Eds.), Coastal fluxes in the anthopocene, Springer, Berlin, pp. 145-200.

Schwartzlose, R.A. and Reid Jr. J.L., 1972. Near-shore in the occidental California Current. CalCOFI Reports XVI, 57-66.

Schwing, F.B. and Mendelssohn, R., 1998. Long-term variability in the seasonality of Eastern Boundary Current (EBC) systems: an example of increased upwelling from the California Current. In: Durand, M.H., Cury, P., Mendelssohn, R., Roy, C., Bakun, A. and Pauly D. (Eds.). Global versus local changes in upwelling systems. Institut Francais de Recherche Scientifique pour le Développment en Coopération, Collection Colloques et Séminaires, Paris, 1998, pp. 79-99.

Strickland, J.D.H. and Parsons, T.R., 1972. A practical handbook of seawater analysis. 2nd. Ed. Bulletin 167. Fisheries Research Board of Canada, 310 pp. 
Varela, M., Prego, R, Pazos, Y., 2008. Spatial and temporal variability of phytoplankton biomass, primary production and community structure in the Pontevedra Ria (NW Iberian Peninsula): oceanographic periods and possible response to environmental changes. Marine Biology, 154, 483-499.

Venrick, E. and Hayward, T., 1984. Determining chlorophyll on the 1984 CALCOFI Surveys. CalCOFI Reports XXV, 74-79.

Walsh, J.J., 1989. How much shelf production reaches the deep sea? In: Berger,W.H., Smetacek, V.S., Wefer, G. (Eds.), Productivity of the Ocean: Present and Past. John Wiley \& Sons, pp. 175-191.

Wilkerson, F.P., Lassiter, A.M., Dugdale, R.C., Marchi, A. and Hogue, V.E., 2006. The phytoplankton bloom response to wind events and upwelled nutrients during the CoOP WEST study. DeepSea Research II 53, 3023-3048.

Zaytsev, O., Cervantes-Duarte, R., Montante, O. and Gallegos-Garcia, A., 2003. Coastal upwelling activity on the Pacific shelf of the Baja California Peninsula. Journal of Oceanography 59, 489-502.

Zaitsev, O., Sánchez-Montante, O. and Saldivar-Reyes, M. 2010. Seasonal variations of the thermohaline structure in the Magdalena-Almejas Bay lagoon system and adjacent sea. Ciencias Marinas 36, 413-432.

\section{Figure Captions}

Figure 1. Location, bathymetry and sampling stations in the subtropical coastal lagoon of BahíaMagdalena. Letters A-D correspond to the four stations located in the outer lagoon zone while the ten stations numbered 0-9 are within the inner lagoon zone.

Figure 2. Monthly average values during the period 2005-2011: (A) upwelling index (UI); (B) air temperature and sea surface temperature; and (C) surface chlorophyll- $a$. The grey circles correspond to satellite records and the triangles to in situ measurements. Dashed lines and bars represent one standard deviation of the seven year period.

Figure 3. Seven year record of the temporary variation of the surface values of temperature, chlorophyll-a, salinity, nitrate, phosphate and upwelling index (UI) in the outer zone of Bahía-Magdalena lagoon. The squares show the monthly average of the four outer stations, and the line corresponds to satellite and 8-day averaged UI data.

Figure 4. Temperature-Salinity diagram showing the lagoon bottom data of the outer (Stations AD) and the inner (Stations 0-9) zone. Shaded and empty symbols correspond to the first and second semester of the year, respectively. TSW is the acronym for Tropical Surface Water; StSW, Subtropical Surface Water; TrW, Transitional Water; SAW, Subarctic Water; and ESsW, Equatorial Subsurface Water (Durazo and Baumgartner, 2002).

Figure 5. Relationships of (A) chlorophyll- $a$ vs temperature and (B) nitrate vs phosphate. Surface in situ data of the outer lagoon zone were semester averaged for each year of the 20052011 period; empty and shaded symbols correspond to the first and second semester, respectively.

Figure 6. Principal Component Analysis (PCA) applied to the in situ surface data of salinity, temperature, nitrate, phosphate chlorophyll- $a$ and depth of the Secchi disk. They were temporary-spatially averaged by lagoon zone and semester of the period 20052011. Letter $M$ and $L$, correspond to the outer and inner lagoon zones, respectively; the following number represents the first (1) or second (2) semesters of the year and the number after the media bar shows the last two digits of the years 2005-2011. 


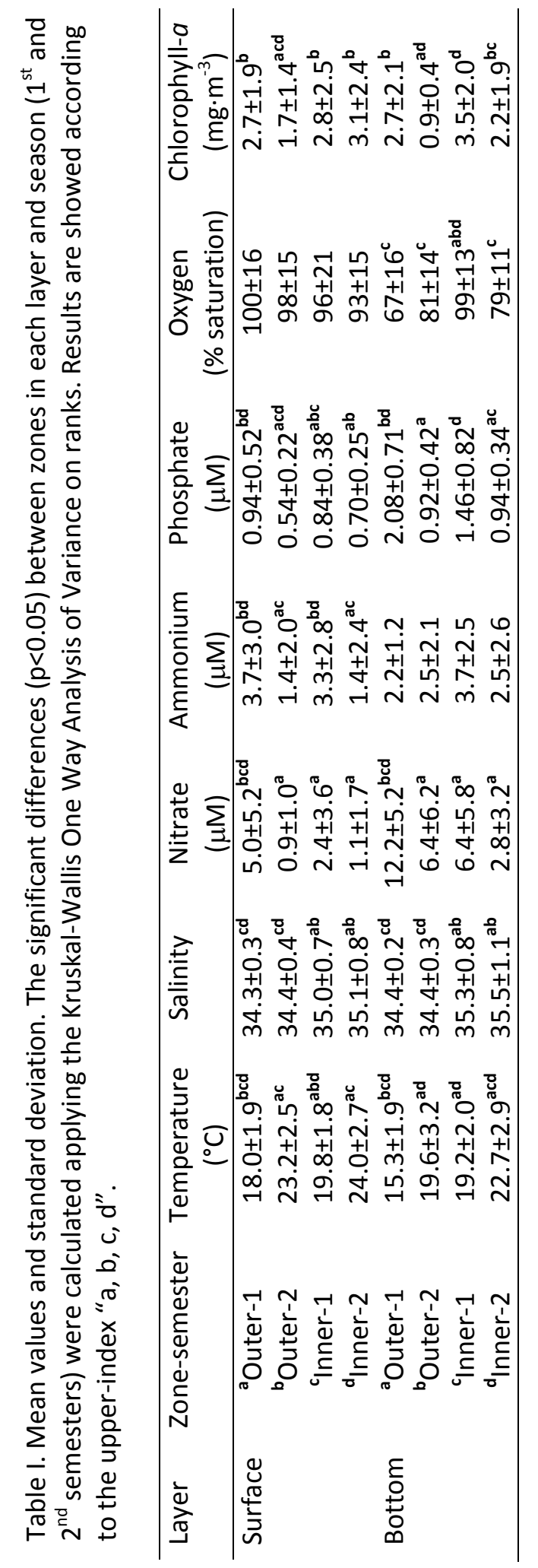




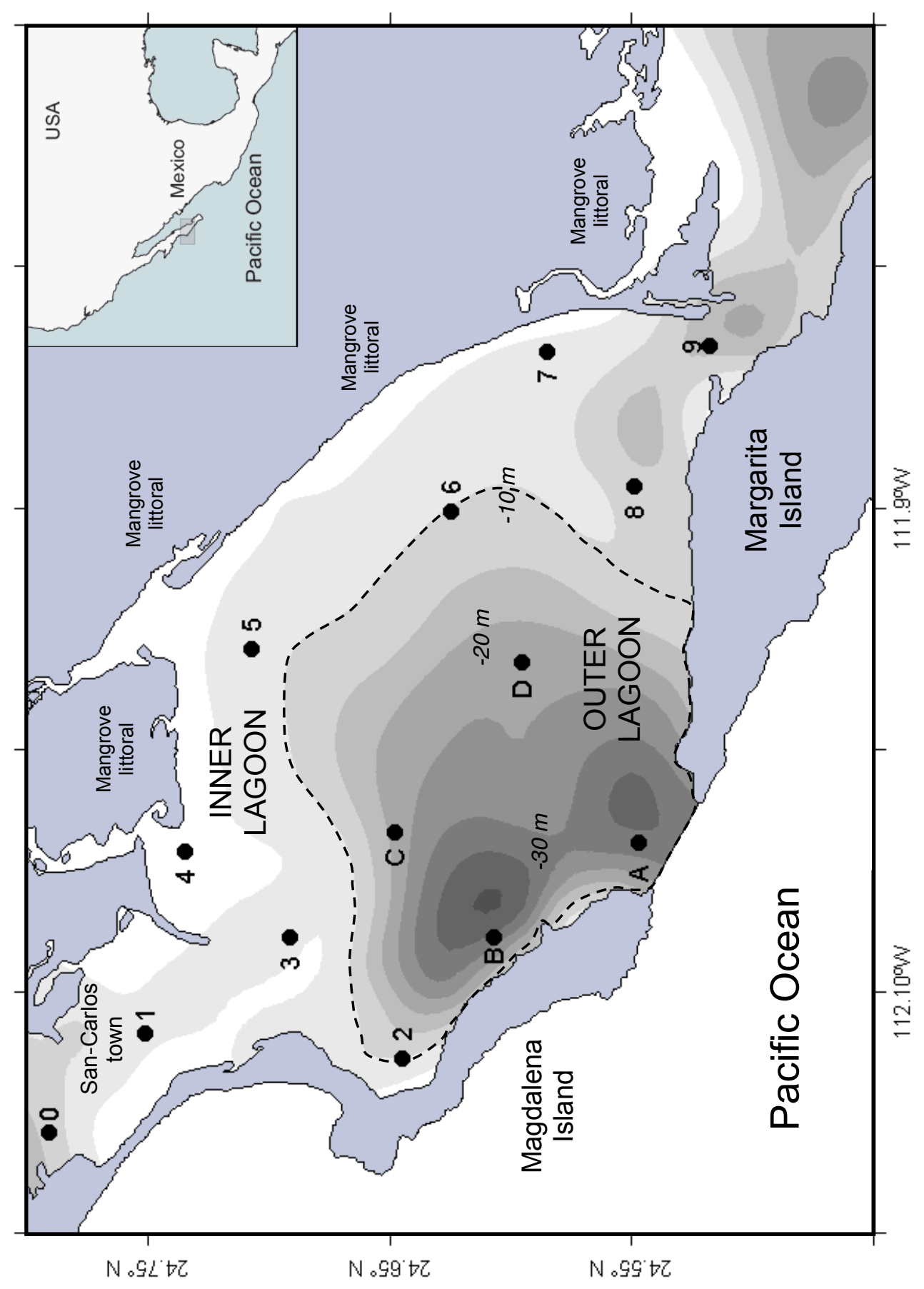



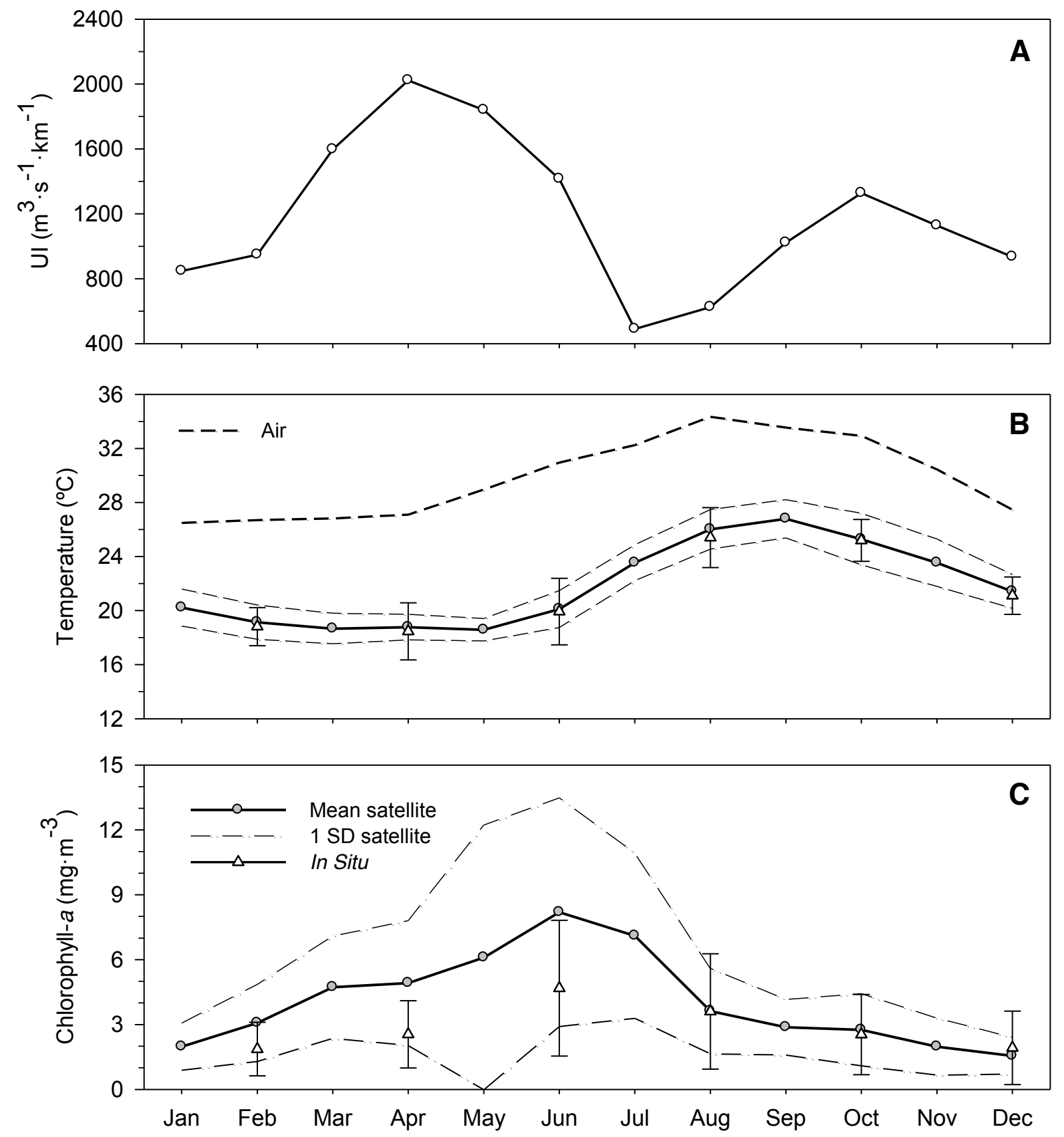

Figure 2 

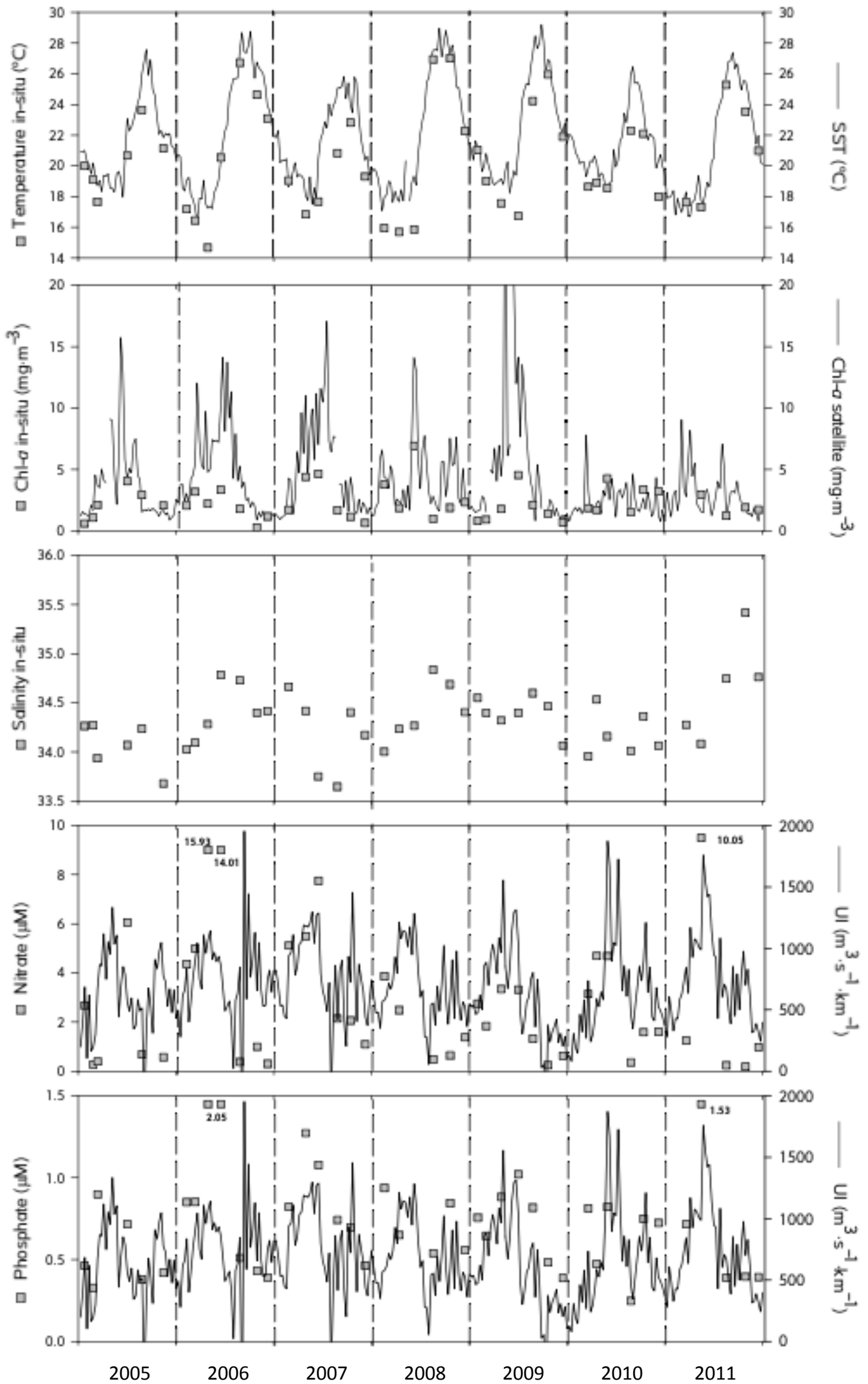

Figure 3 

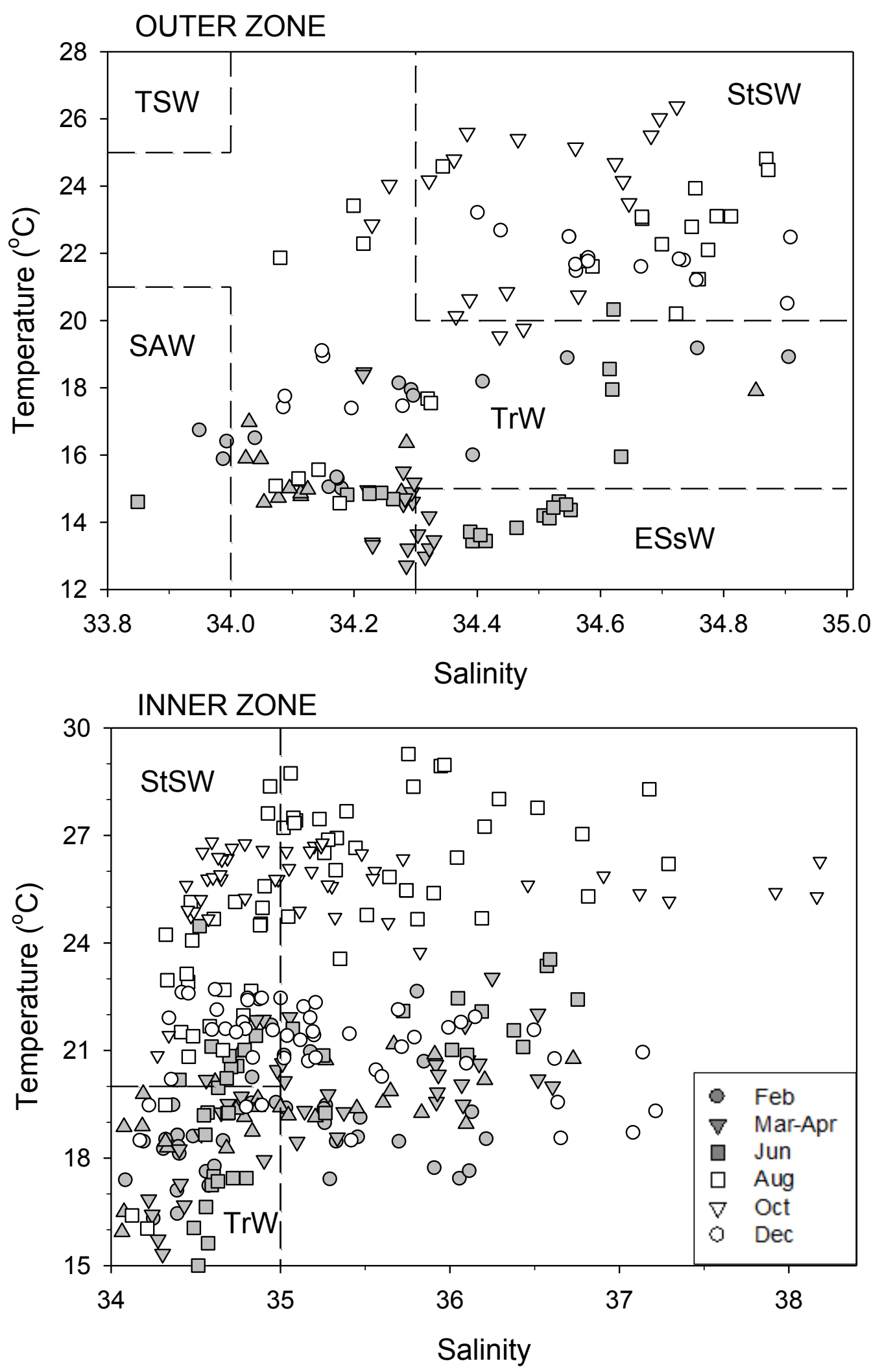

Fig.4 

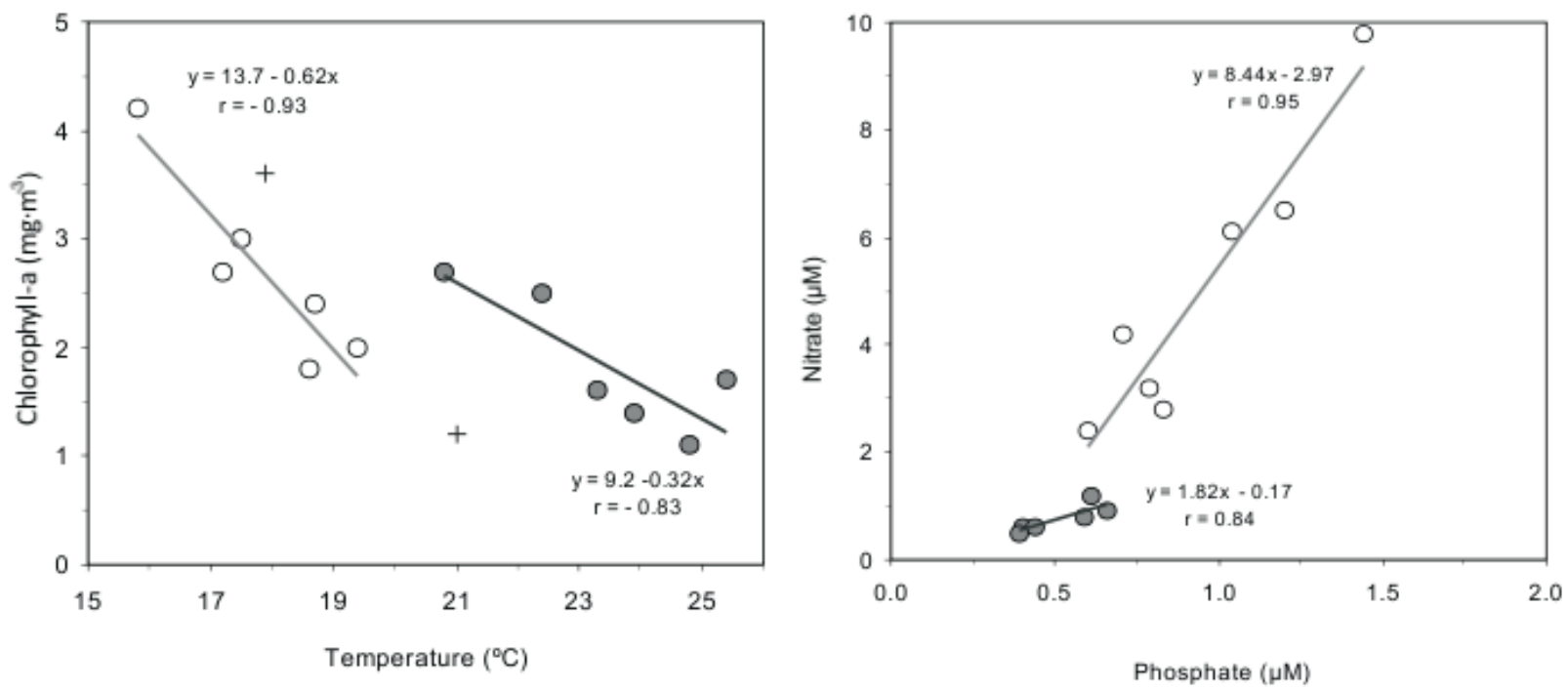

Figure 5 


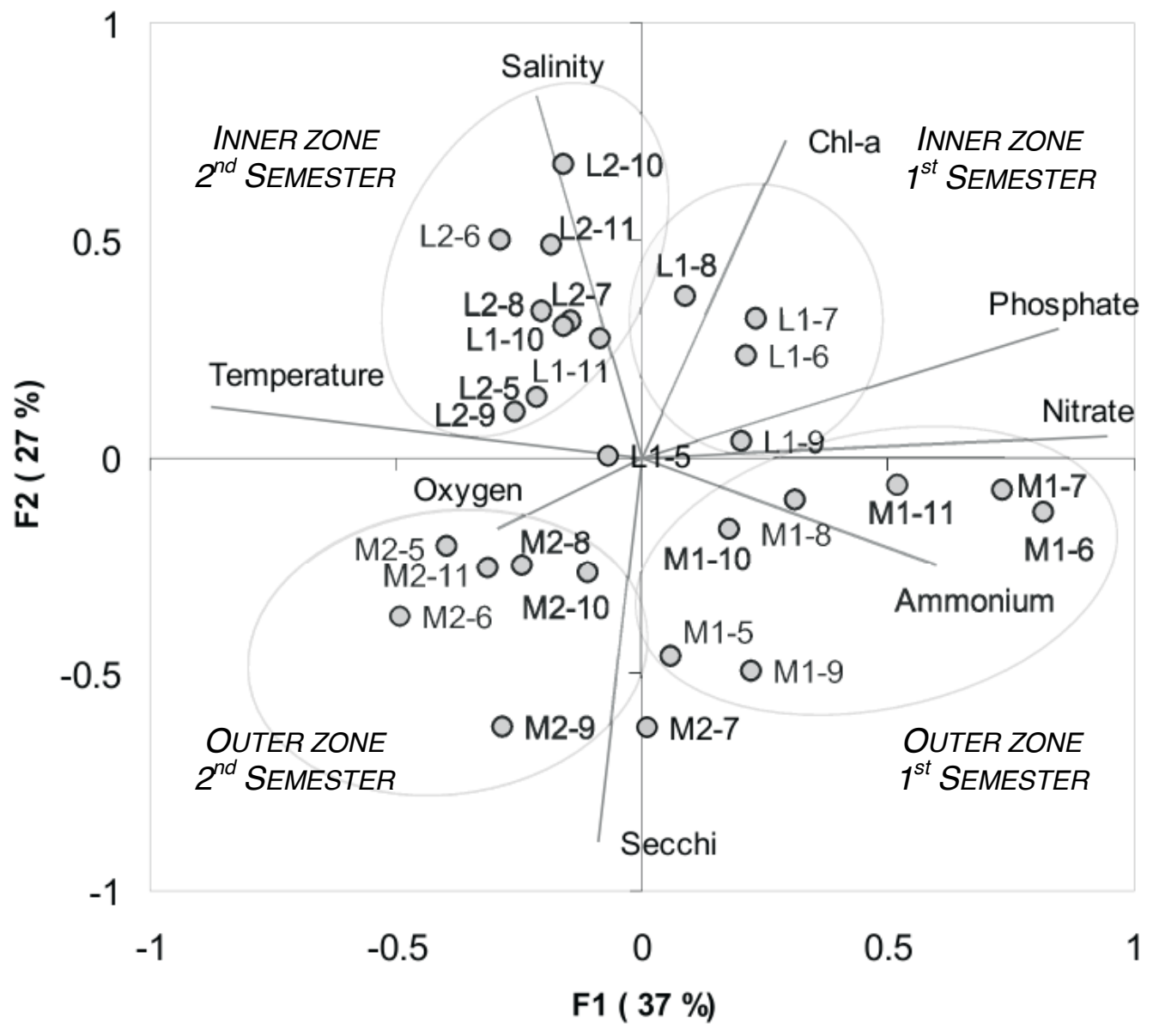

Figure 7 